\title{
複句における分句の連接関係
}

\section{大河内康 寻}

\section{$(-)$}

本稿でとりあげる主たる問題は，被们门う

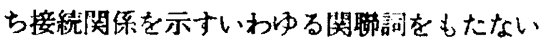
もの，とりわけ速詞をもたないるのの分问問 の関俰を扱らことである。たとえば，ある衫

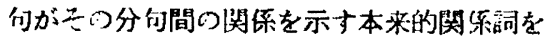
もたない斿かわわらず，ある特定の意味

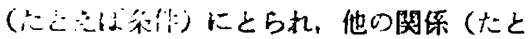
えば因果や轱折など)にとられないのはな山゙ か。文脈以外に，それ自身のちちにこの関倸 を示す指漂があるのか。あるとすればそれは どらいら形であるのか。つまり関距詞をたも

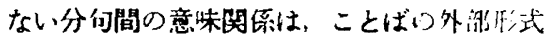
としてはどりよらなものと結んでいるのかを 考えることである（注 1)。またその結果とし て、第二の問題，仮説としての「菜表現」と いら私胃に阿単に尔れてみたいと思5。

本稿てとりあげる対象は被们のうち㑡正䙓 付とよばれるもの，つまり各分够か主従関係 にあるものに限る。しかしまた偏正関係にあ

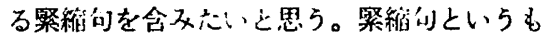
のが本稿でとりあげる放问の遇接関係と，抢 は同じ問題をはらんでいると考えるからであ る。したがってある言い方をすれば、ここに とりあげる対象は下命題文」とでも灾心か

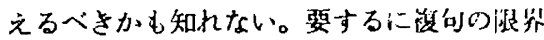
についてはすっきりいかないのが悟であ り，種々の見解があるが，今ここで部ずる衫 们はその議渝を前提としなければならないよ

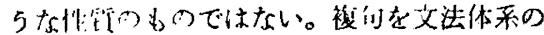

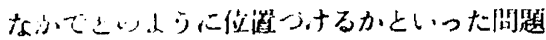
とは，かかわりをむたないところで扱ってい るということであってかなり幅をもたせて
法えた腨正复句である。

複句の連接関係がことばの外部形式とどの よらにつながっているかを考えるに当って は、卞複句の分句間化存在する意味関係を 整理しておかねばならない。しかし被问の分 们間に存在する意味関係はまことに袮雑であ う。とりわ线合複们といわれるものに扰い こはまったく微妙な関係でつながっている。 といらよりそれ以前の問題として，どらして それを被问と考えればならないのかといった 独立した各何が逗号で，または短い停頓でつ ながっている。当然その間に意味の差を求め るならいくつにも分れることになる。黎錦熙 や澡世檽は笪句の連接関係を36類に分けてい るが，おそらく現実に見るものはなおこれだ けで律しきれるものではなかららと思われ る。ある見方をすれば，このよ5に意味の上 で細かい連接関係を考えること自身が，中国

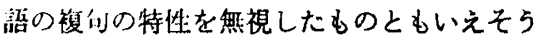
である。

本稿で問題を偏正复句にのみ限った理由も 其はそこにあるが，なによりも明雄な諭理関 倸に從って分们閪の意味の大枠を設定したい からである。分的の意味的関係を十分説得的 に規定しえないしのをとりあげ，それに忘ず る外部形式を求めることは二重の難しさを背 負らことになる。一般に行われている分類を あげると次のよらなものである。

「漢語」の体系では蛙折，因果，条件、目

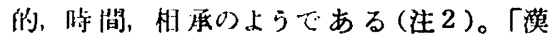
浀」の体系老説明与ることを目的として書か

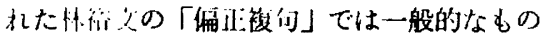
として因果，条件，砟步，転折をあげ，これ に特殊な二類を加えている。黎錦熙，钢世儒 
は因果，仮設，条件、㯖歩，時間，比较を立 てている (注 3 )。「漢語語法常識」で偏正に 属すると思われるのは転折，因果，条件およ び複雑な関係一類である。「語法講話」修訂 本では因果, 譲歩, 条件についての及説明を 与えている。さらにこの他，仮託，連鎖とい ったものを立てる立場がある。

立場として，細かく分けるものと大きな類 を立てるむの，諭理関係だけによるものと，

「連鎖」の上らに語法関保（連鎖では代詞な どが関連して用いられること）を考麀したも のとがある。しかし本稿で扱ら問題から必要 とするのは細かい分類ではない。明確な論理 関係がたち，かつそれにほぼ応ずると思われ る語法関係が認められるよらな大枠が必要で ある。もっとも，このことは無前提に決めら れる問題ではなく, 後の分析の結果を見合わ さなければならないが，その結果をも考文あ わせ，論理形式の大枠として，次の四つの関 保を設定する。

\section{因果関係転折関係}

条件関係䛠步関係

この四つの関係である。連詞をもつ複何から いえぱこの四つの大枠はそれぞれいろんな 関係を含んでおり，満足すべきものではない が，十分な関聯詞をもたない複句にその小枠 を求めることは無理であり，この大杵で分句 間の意味を一応明確に捉えることができると 思われる。

\section{(二)}

次の文は文脈をはなれるならば，因果，条 件，㖣步，転折のいずれにも読めそらである (注 4 )。

\section{1. 有党支持，他排不住阿。（注 5 ）}

（因果）党が支持しているんだから，か れはじゃまだてできないよ。

（条件）党の支持があるなら，かれはじ やまだてできないよ。

（謫歩）たとえ党の支持があっても，か れは（この鯰湈を）阻止できないよ。

（転折）党の支持はあるんだが，しかし
かれには阻止しきれないよ。 この上らな例は論文，論説の類には少い。し かし，小説，とりわけその会話の部分中話䃍 ではけっして珍しいものではない。つまり話 しことばの世界ではこのよらな表現が韻解さ れずに通っているのが中国語である。しかし このよらな文の正しい理解は，それではまっ たく文脈に依存するより仕方がないのか，と いらことである。事実は必ずしもそらではな い。もっともこれは端的な例であるが、これ に近いすのはむしろ複句の常態として通って いるのである。

一般に関聯詞、または関聯詞䨿とよばれる ものは，連詞を除いて一部の副詞，代詞，そ れに固定格式とよばれるもの「維……，誰… …」一-…...就……などがあげられる。こ れには広くとる立場と㹟くとる立場があるが (注 6 ), 固定格式といわれるものは，きわめ て常套的なものを除けば，1の例と本質的に そら变るものではない。

2. 要根除三害, 先要除掉思想上的病害。

3. 要経得起誤会, 要向雪鋒学習。

4. 没有革命前䧳在山蒘里斗争，没有中 国莑命的勝利。

5. 不当家不知米贵。

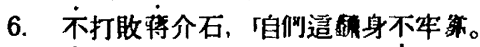

7. 少吃需食少生病。

8. 吃一整長一智。

これらの例はいずれも，連詞や関連作用をも つ副詞をむたないにもかかからず，条件関釈 でつながる複句である。その理由はしばしば 「要……要……」「没有……没有……」「不 ……不……」,「少……少……」一一……… ……などに求められている。たしかに 5 の 「不当家不知米贵」を，「不」を除いて「当 家知米贵」ではその意味をとりがたい。少く とも「才」を加えて，「当家才知米贵」には なろう。しかし「要……要……」、没有…… 没有……」などがあるからといって，一䔐的 に条件関係が煘きだせるものではない。1の 例とそう变らない部解の危険性を汸らんでい る。他の関係でこれらの語が統いて現われる 
場合がそら珍しくないからである。たとえ ば：

9. 俩叫要聪話, 要服従命令。

10. 我们雨都没有結婚，没有家務事。 9は並列であろうし，10は因果関係といわね ばならない。さらこもっとも常套的格式であ る「誰……誰……」のようなものも：

11. 如今全家都是当家作主的公社社員, 淮都可以過問，誰都可以管。

この例で「誰」の呼応関係があるとは惩めが たい。また同じく代詞を呼応させたもの：

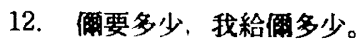
においては呼応によって条件闺係が生ずるわ けであるが，次の例においててはむしろそのよ らな説明がじゃまなものとなる。

13. 雨怎么一塊一塊的罣，不干洈置多少 要多少呢:

また「先到先賈票」には「先」の乎応阅保が あるといわ机るが、「先別考蝔思想問題，先 看看他叫過的什磨様的生活」ではこの関保 は立てられそらにない。固定格式といわれる ものが，いずれの場合に㧅いても决定的役割 を果すわけではないのである。つねに格式と いらものから捉える限りにおいて，誼解の可 能性をはらんでいるといわねばならない。つ まり連接関係をみることつの目安といらこと である。

しかしそれでは，連接関保にはこのような 格式以外に目安はないのか。つ方り連接関係 はこのよらな形でしか現われないかといらと 必ずしるこうではない。並列などはさておく として，因果や条件なとには次のような差を 見出すことができる。

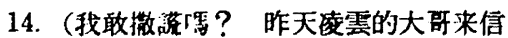
説：）淩雲的嫂子也有了工作, 毎月 可以多給我十塊銭。……因果

15. 有了工作，她毎月可以多給我十塊銭 ……条件

14では「手紙でいってきているよ5に，嫂子 に仕事ができたので......」といら意味になる が，この文のはじめの「淩雲的嫂子也」まで を除き，後句のはじめに「她」でも補らと，
15の「仕事ができたなら、かの女は…..」と いった条件何になる。

16. 我現在不能学開坦克, 学学開汽車。 ……因果

17. 不能学開坦克, 学学開汽車。……条 件

16は中国語に親しまれている人の感賞からす ればすぐ「今わたしは…‥できないので，し かたがない.........上ら」と理解される。実は この感覚といらものがはななはだ問题であるの だが，これに反し17の方は「……できないな ら，…ㄴ上ら」といらことになる。つまり 前句に「我現在」が加わるかどらかが分佝間 の関係に大きく筒与しているのである。

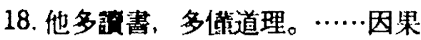
この例は「かれはよく勉強したので，よく物 を知っている」とよむか，「かれはよく勉强 し、よく物を知っている」と並列によむかで あろ5。しかし：

19. 多窟書多愅道理。 では一般的命題についてのべた条件句であ る。「よく勉強すれば道理に詳しくなる」と い5のが普通の理解であろら。これは「他」 が前句につくかどらかといら差である。

20. 他在雨這兒好幾年了, 雨大概也看出 来底子。……西果

21. 在俩這睍，雨大概也看出来底子。… …条件

20は「かれは長い間あなたのところにいたの だから……」である。21は「あなたのところ にいたのなら……てでる。ここでは前句に おける主語ばかりでなく，「好幾年了」がつ いていることが連接関保に意味をもっている よらであるが，ともかく主語の有無が分何間 の連接に働いている。

またこれとは別に，次のような差も見のが すことができない。

22. 雨現在是副排長，連里對俩的要求会 更留一些。……因果

23. 要是副排長, 連里䟵雨的要求会更跭 一些。……条件

24. 他現在有不少進歩, 千万別憕冷水呀! 


\section{!……因果}

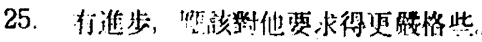
……条件:

22 と23，24と25はほぼ似た文を亚べたお，のて あるが，その一方は「…..ななで......」と因 果の意味でつながり，他方は「…‥ならば… ‥」と条俳何に上机ばならない。ここでも 条件句に主語といらべきもが落ちているわ けであるがまた別の兒方をすると，ここで は一うゔて現在」といった副調が入り，他方 ではそれ们ない。いらより，むしろ「要」 といったちがったことばが入っているのであ ろ。このような例は珍しいものてはない。因 果，転折们に属するものには「違然，遭個， 那個、那様」の上らな代詞、「已経，起初， 現在」のような副詞がしばしば用いられ，策 件，譲步们には「要，該，敢」のような能䁰

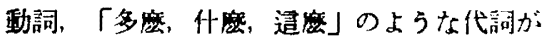
しばしばあらわれる。たとえば：

26. 家里這麼熱䦗，我在外辺待不估。… …因果

27. 咱们有這摩個好班長，保持四好班是 有希旺的。……因果

これらの句の前句を次のよらに改めてみると 連接関保はまったくちがったものとなる。え6

「家里多密熱䦌」，27「有好班唇」つまり

「這麼，䢣麼個」「多麼」などの果す役割が

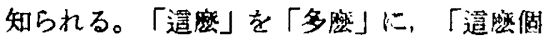
好班長」を「好班長」に变えることによって （27では「䀦何」をも除くが）好果们は条件 们に億味を変えることができるのである。

このことは転折们にけいても同様である。 次のよらな例がある。

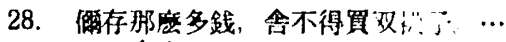
…転折

29. 存多少銭，他舎不得資双被子。…… 旅歩

28は「あんなに拉金をためているのに，․」 であって転折であるが，29では「たとえどん なにためていよ5と，…‥」の意味で䏝步と なる。その差のひとつの由来は，一方が「那 磨」であるに対し，他方が「多少」であること
に認めることがてきる。

またい妄ひとつ，戌溯詞をもたないるのに

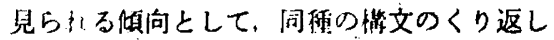
があげられる。

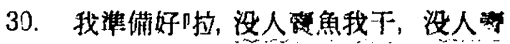
菜我干。

31. 灰鹿不接不掉, 敵人不打不倒。洪水 也是一槏，……

この二つの例はいずれも条件句であるが，あ る見方をするなら、これは「魚を睤る人がな いのでわたしがやる」や「磨についてはま ったく挪除むしない」といった因果や並列と とら乱る誤解をさけるためにくり返しによっ て明確にしているといえる。もちろん因果句 も偏正䙓向のひとつであるが，同じく编正篗 们つなか心志っても，因果何や転折句とい5 ものはその接綂閶係の流密の点において，条 件们や辞歩们とかなり性格を異にする。これ は後にも速べると拈りであるが，条件句や讓 步们り防机いてこそ連接関係を明確にする ことを泪られるわけであって，ぜひ速接関係 の誤解をさけなければならないが，そのひと つの片法として、このことは理解できる。

以上妾愍して、十分な関聯詞をもたない複 何において，その分们の速接関係を示寸指㬓 としてこのような「前句の㠿染の有無の問 題」「前们のある種の副詞, 代詞の作用の閭 題」「闰垔の複们の重权の問題」を考えに入 れてよけのである。とりわけ前二者はかなり 一般的な原則として数副できる可能性をはら んている。もちろんこれも目安であって決定 的条件てはないが，目安は多、万がさいかけ

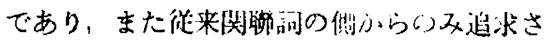
れてきた複们の関係を，別の側面，複何にお ける分问のそなえるべき条作といった側から 追求できのではないかと思ら。招てらく複 句つある種のものだ，どんな文でも従句に なれるわけではなからうと推測されるが，そ れではどんなものが一般的であり，どんなも のが除かれるが考えてみることが必要なの である。 


\section{（三)}

ここでは因果，伝折，条件，变步の各们に おいて，先にのべたある種の副詞，代詞など の役割を考えてみたい。

少し極端な言いうをすると，中国浯に樃向 といらものが存在するのかとい5济㖮がなり たつ。つまりそれほど中国語にお汁る複甸の 分句間の関俰は做妙であり，かつ椱句とい5 概念で考えられるような们と们の嘧接な接続 関保があるものは少いということである、䙓 们といらものを，単に逐号や小停頓の孙から 捉えた文法論にお汁整理の一泃と割りきる なら简単であるが，ややもすればての間に単 独の文の速統とはちがった祭密な意味的成釈 を求めがちな一般的立場から寸れば，中国哣 には類句として似つかわしくないるのが多 い。たとえば次のような例がある。

32. 時間到了，年門了，沓別了，親爱 的应子，我倗去丁，傣可不要忘本，

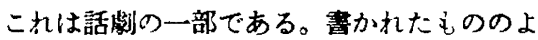
らに整理されていないところがねらいである

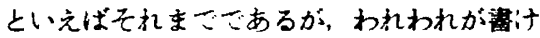
ばいくつもに分けるであろう们が逗号で続く のである。どうもこれが复何であるとはいい にくい。もっとも日本䎸にも同じよ5垷象 は市るわけで，一頁にビリオドひとつとい5 文珍しくない。しかし月本語のよ5に「斬 用」「終止」といったての摽示をもたない吅 国語では事態は複雑である。少くとも北録す る立場からい充ば，どこで切るか，どこなで 続けるかは個人の心理り開題にすぎす、全䉘 一文といらことも可能となる：事俸朱で们幦 を切りながら読まれた古文や旧小説はそらな っている。このことは近代的な標点符号の歴 史が浅いといらこともひとつの大きな理由で あろ5。しかし一方また中国唔といらことば が，本来そ5いう性格をもつといらこともい なめないのである。32の例について，分句と 分句の間の意味的連接阅係を求めれば一体ど らいらことになるのか。読む人によって，ま
たその時によってかなりちがってこようと思 われる。このよらな関係の間に，適当な速叮 を入れることはまったく㫮理な听である。中

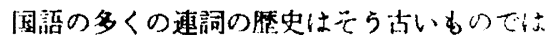
ない、中国婹の繁问といらものは本米速詞を 必要としないのが常態であり，むしろ使われ

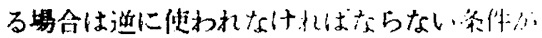
あるからといわね舛ならない。师折のとはし

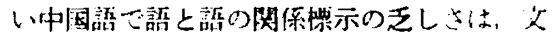
のレベルニおいても似た占なものであると い之よらか。

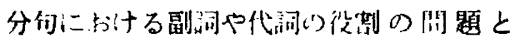
は，帮は已然麦現、本然表現、あるいは確定 表現、化倠定表見といらことであるが，これて

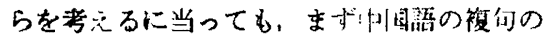
もつこのよらな性格をひとつ考凬に入れてお く必要がある。

因果们，軾折问，条件们，旗步句の間には 次の上らな関倸が文てられる（注 7)。

\begin{tabular}{|c|c|c|}
\hline $\mathrm{I} \quad 11$ & 巴然表現 & 末然表現 \\
\hline 傾接関保 & 因果 们 & 条件 们 \\
\hline 道接 & 転折句 & 棣少们 \\
\hline
\end{tabular}

偏正数们の従们はてれでれ二つの条件で規制 されているといえる。Iは従们と主们の一般 的関係として，尺れが順接であるか逆接であ るかということ。Illは徒们の内容が然であ るか・未然であるかといらことてある。この二 つの条件の組みあわせによって，因果，枟

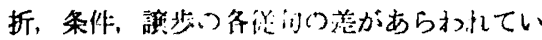
るといえる。ここでいら巨然表現とは、從问 の表現内容がすでに行なわれたもの，すでに あったものといらばかりてなく、たと行な わ机ていなくてら行ないれることが明滩に皮 証されているものを含む。同㴍に未然表現と い5のも，行為，行䡃として末然であるばか りでなく、その行なわれることが末矢証，末 確認であることをも含んでいったものであ る。

順接壁係にあり，挝闪が然であるなら，

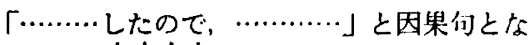


る。また順接関係で，従句の内容が未然であ るなら「……..するなら，……..」となって 条件句になる。他方，分句の関係が基本的に 朔接であるなら已然では転折句，未然では諨 歩句になるといら考えである。このことは一 般的論理として成立するわけで，日本沿に末 いて教えてみても容易にらなずかれる。もち ろん，したがって中国語の語法事实としてこ のことがあると速断すべきものではないが， 偏正们の従何を调べてみると多くの们にその 反映が見ら机る。

すでにあげた例22．23．24などにおける 「現在，要」はそれである。また次のよらな 例があげられる。

33. 要学習, 時間有的是, 問題是我们善 不善干捐。

34. 要知道今天清算准老昆, 他们保准来。

35. 要想創造四好連, 要有四好排。

36. 想喝酒自己家里喝不開。

37. 該干什㦄干什㦄。

38. 能記住這幾条, 我算一塊石頭落了地 啦。

これらは従句に未然を示寸語がそえられるこ とによって条件句，翼步何になっているもの である。ここで「要，想，該，能」などは， もちろんそれ目身の語集的意味をむつが，同 洔に未然を示寸ことばととってよい。つまり これらの前句が未然表現であることの証佐と してこれらの語を見ることができる。

「要」については，「要」の語出的意味が 仮設を示すといら考えがあるが，本来的には

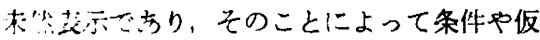

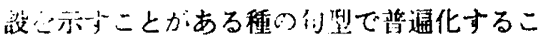
とによって，そのよらな考えが生じたものと いわねばならない。とりわけ実際の表現とし て、「我是学生」の上らな「是㩲文」をここ でいっている意味での未然（注 8）とするに は，「要」をつける以外に方法がないである 5。いき批い㴗是学生」といわ杖ばならな いことになる(注 9 )。この「要是」が，「是」 が必ずしも単純なコプラといえない中国語の 性格とあいまって，弱化し，仮設を示す接続
詞といった記述が辞書でなされる結果にな る。したがって，この「要」も「副」や「想」

「能」と本来的に同し性質のむの，つまりい ずれも未然を示寸語のひとつと考えてよいと 思われる。

36. 37，の例に淤る「想」中「該」は， たしかにこの句全体の意味に「……したい」. 「……すべさといった「想」や「該」その むののむつ意味をそえていることは事実であ る。しかし同時に一方では，この句を境步や 条件们に位眉つける重要な作用をしているこ とを見のがすことはできない。「想や「該」 があることによって，確実に諆歩や条件によ まれるよ5規制している。一部の副詞をむ含 めた他の関聯詞をつけずにこのよらな表現 以外に他にどのような表現がなりたつのか， 䇠単には想像できないのである。38の「能」 においても近いことがいえる。

しかし因果，転折们に扒いては，これと対 照的に已然を示寸浯がきわめて一般的であ る。

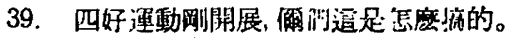

40. 大雔己経回来好多天了，我的凍骼選 没好。

41. 正好支委都在，婏上開個支委会研究 研究吧。

42. 他馾馾早死了，他想什么? これらはそら珍しいものではない。因果や転 折们における分句間の結合度は条件中㜔步注 ど案密なものではなく、いわばどんなことを いっても分句を並べてみて因果関係などがつ けばよいといらほどのものであるから，条件 や蛽步们が未然を示寸語をむつのとはその役 割がちが5といってよい。ただ条件，鿁歩们 にみられる末然表見といらものが、ここでは 已然表現となり，ての反胦ともいらべきこと ばが「㓮，已経，正好，早」などによってあ らわれているといらことである。已然を示す ものとして典型的なものは「既」「既然」で あろらが，本来已然であるところの因果们の 従句の已然性をさらにはっきりさせるものと して捉えてょいであろう（注10）。 
また末然表現の他のひとつのあらわれとし て、本来「没」や「没有」であるものが「不」 になる例をあげることができる。

43. （我這次下了決心，）入研究出来我 決不休息。

「研究出来」は堨向補語「出来」をともなっ ているわけで、本米「没，没有」で否定され るのが普通である。しかしここでは条件们の 従句として「不」によって否定され，それ が，この句が条件句であることを示寸ものと なっている。これは一般に語法書で指摘され る原則をはなれるが、これは後にのべる偏正 複句の従句などにみられるところの特別な表 現形式として注意されなければならない。ま た一般的に，条件们中讓步们门従们の述沿動 詞の否定に「没」が使われる例はまずない。 たた「没有」が出るが、これは「不存」を 示す「没有」のみであり、「不有」がない以 上当然であろう。つまり imperfective なも のの否定としてある!没，没有」は，未然表現 である条件や蛽歩句の损句ではその役割を失 らわけであって、そこにある動詞がperfective なものとしてある以上「们がとって代ると いらことである。

また今ひとつ，末然表現といらことのなか に含めなければならないのは, 確定的表現に 対する「不確定的表現」といらことである。 すでに26. 27であげた「這㦄，這應個」など に対する28. 29の「那整，多少」などであ る。さらに例をあげると次のようなものであ る。

44. 遇見什㦄麻煩都先跟我来談談。

45. 病人死了多少, 他是不管的。

46. 唡去多么早, 他説雨避到。

47. 開個証朋書, 在外面好辡事。 これらの例忏次の因果, 転折句と対比される べきものである。

48. 聴了這㦄有意思的話，我下了決心。

49. 我活了這巍大歳数，還没有在大会上 潾過話。

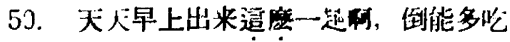
半晼飯啦。
末然表現の当然の㷌結として，事実を明確に 指定しえない性格があるが，その反映として 条件，諆步句にはしばしばこのような語が用 いられる。44〜46の例の「什㦄，多少，多㦄」 などである。47の「個」が不確定表現である ことはすでに一般に指摘されているとおりで あり、これもその一種とみてよい。これらは 因果句や転折何では48〜50にみられるとおり 「通麼」や，あるいは「那㦄，遭様，那様」 といった指定表現におきかわる。われわれは その間にみられるこの対照に注意してよい。 もちろんこれらがつねにあらわれるものでは ないことはいらまでむないが，策件们，撞步 句はその性格からいって，このよらなことば がしばしばあらわれる可能性をひめており， その具体的あらわれが珍しくないといらこと である。44の「遇見什紧麻煩……」は「遏見 麻煩……」であっても，条件们であることが 変るわけではない。「遇見麻煩」であって も，その「林煩」は限定語がつか奴限り賓語 とい5位值からも，不特定の「麻煩」であり， その意味で全体がなお不確定表現である。し かし「麻煩」に「什麼」がつくことによって， この不確定性は一層明確に示されるわけであ って，条件句の従句であることがさらにきわ だつといってよい。後にのべるが，条件句や 埕歩句に主語を欠くことが多いといらのも， 実はこのことのひとつのあらわれである。つ まり確定表現，不確定表現といら立場からす れば，明らかに主語，主題なるものは文中に 括ける確定要素であり，従句のもた杖゙゙なら ぬ不確定といら性格と相反するものとなる。 とりわけ限定語をともなった長い主語, 主題 なるものは入りこむ余地を失らのである。そ の結果として主語を欠くことになるが，これ も未然表現のもたらすものとして理解してよ い。

ともかく因果句や枟折们に扣ける已然，条 件们や誶步们における末然といらことは具体 的に多くの複们につらられるわけであって，分 们の速接関係をとらえる上でひとつの目安と 考え注意さるべきものである。ただここでつ 
け加え杖ばならないのは，已然末然といら ことはどのことばとごのことば，どのような

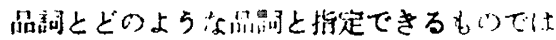
ないといらことである。むちろん大的のこと は寸でに指摘したとおり出てくるが，それは どんな文中においてを种对といらものではな い。

51.（湖家有幾十斤花生米），過了夏弪 走了油㗅。

この例に扰いて「夏天」はこのことばの詰 されている㘯酸に批いて本然表示ととれる。 しかしそれは夏を前にしているとい5前提に 立つのであって，「夏头」がつ极に未然表示 の架といらわけではない。

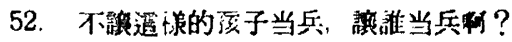
この例:打忛方「通棁」は，条件何の従呵に 使和机ているわけで，不確定性といらことに 反十るともいえるか，この们大閒最二圭って

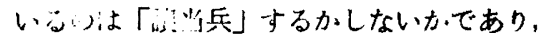
不確定性はそこにある。した心゙の二「造瞵」

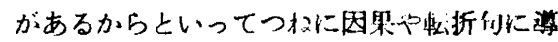
かルるといらもりではない。しい，明確な

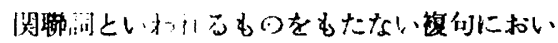

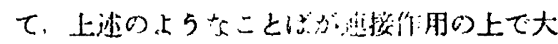

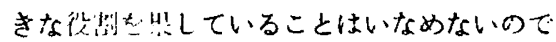

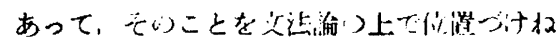

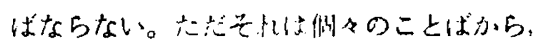

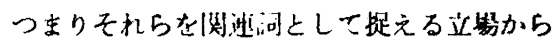
するりはむ年かしいであって，むしろ徉何 として成立するための条件といら侧から提え

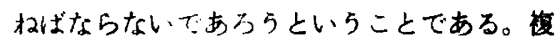

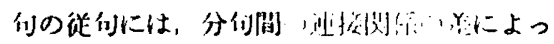

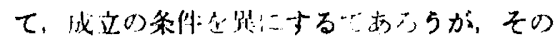
条俳のちがいのンとつとしてし然，米然ある いは不確这表現といらこと胃その其体的

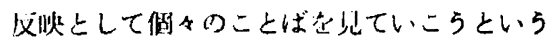
のである。

（Iの条俳としてあけだ順接逆接といらこ

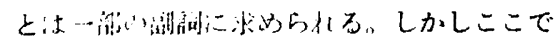

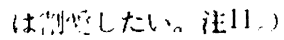

(讪)
すでにあげた15，17．19．21の例に見られ るとおり，偏正们のうち，条件，境歩们倔 するものにはしばしばといらより多くの场 合主競が抵ちている。さらに二，三の例を抬 5と:

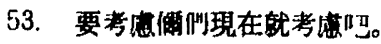

5.4. 見了工作他就干，遇着了伦険，㙟着 也要上。

このよらに主語がおちる。また主語が従敂で おちるばかりでなく。主句にはその補いとも ら見れるべき主語がしばしばつく。上例で 「譧何」甲「他」か主何についているのがそ の例である

これはつねにそこであるといらわけではな い。速接関俰を十分に示す関聯詞がついた場 合はどのよらな主哣がついてむよいことはい らまでもないが，十分な関聮詞がなくとも主 語がつくことがある。したがって「多くの場 台」といわ杖ばならないが，主讙のないのが 一般的である。

この主船のないのが定型化したのが，「不 信」、「不行」、「聼説」などである。

55. 不信灀叫俑大娘説説。

56. 大嫂獬去試試，不行再説。 5うつ例主初学者はよく「おまえが大娘にいわ せて友せるなんて信じられ奴」と訳す。この

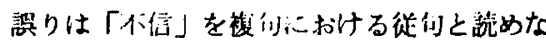
いところにあるが、これを初学者に十分説得 的に説明することは難しい。「不価」がはじ めにくればしばしばそらなるといら程睮似理 解にもとづいているからである。しかし罢は このことも，前になにもこないといらことが 重要であって限定諱のついた主棓でもつくと 一梅に条件とはいいがたくなってくる。「我 㯖説……といらこともないわけではない が，「罒くところによれば」としては「鳃 説」の方がとおりがよい。

このよらな事俏はさらに次のよらな例にも つながっている。

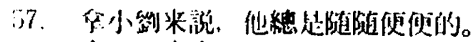

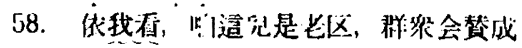
的。 


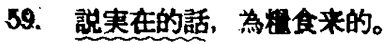

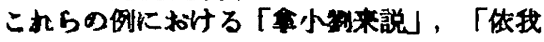
石」、「説実在的話」はひとつの定型として 理解されている。とりわけ「依我看」などは 独立成分とされるわけであるが，本来的には 条件句の従句であり、主語や限定語が多くつ かないとこらから、このような理解が生じた にすぎない。したがってこれらのことばを本 来に立ちかえって考えるなら，条件句中㜔歩 句の従何にしばしば主語や限定語がつかない といら次元の上で考えてよい。

そこで炊にこのよらな現象の起こってくる 由来を考えてみると，条件句中諟步句の従句 は未然の事赛として提起されるわけで，すべ てが作定として出ているといらことである。 仮定である以上、具体性をおびた描写は存在 しないことになり，事実として成りたつかど らかが問題である。したがってこれらの従句 には長い状語がつくことはきかめて少ない が，それと同じ元で考えると，「誰がどう こらする」といらことは問題てなく、すしろ 「とうこら」するかしないかが闍題になって いろのである。ここでいら主語とは主題とい ったものを含むが，主語，主題というものは すでにふれたとおり文中における確定要素で あり，その意味て限定的である。したがって 事態の成立不成立とい5面からのみとらえる 立场からすれば，上けいなるのとなる。しか しこれに反し，因果句や轱折句では従句がす でにある事実についての具体的叙述であるか ら, 当然主語, 主題といったものむ明らかに されねばならない。

60. 我覚着對不起他, 馬上坐火車 往 回 䞨。

これを複句と考えることには異論すあろう がともかく意味的には因果网係の重接であ る(注12)。「我」は前句にも後句にもかかる から前句の前に漫かれている。因果句とい5 あのは, 後句がある事実について叙述してい るのと同じように前句むある事実についての 十分な叙述をしている。聯合硕句におけるよ らに対等ではないにしてす，後句に依存しな
ければ単独で存在しえない前句ではない。 「従句」とはいえ，その意味するところは条 件、諩歩句などとはかなりちがら。したがっ て，主語，主題といらすのをたてるなら，前 句の前にあらわれて当然といらことになる。

一般に俑正句の従句が単独で句として成立 しないといら説明があるが、これは連詞を落 えるからであって，因果句や転折句において はその分句から連詞を除くなら立派に们とし て成立するものが大部分である。「因為風太 大けだけでは詰いきりにならないが，「因為」 を除けば「瓦太大」だけで十分な単蚛の表現 である。しかし条件，転折句ては事情がかな りちがう。それは従句というものが，主句を 予测しないで性立しない詥理をむち，主句

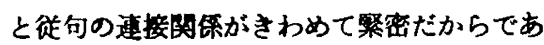
る。したがって主語をたてるとするなら，従 句ではそのことがらの成立不成立だけをまず 提起しておいて，それに対して「誰が」「何 が」どうするといった一般的叙述は後句に梳 けるのである。

こら考えると，条件句中䜖歩句では主語が あっても，その主語にはかなり制限があろら と想像される。確かにいくつかの制限をあげ ることができる。まずあげられるのは，主語 がある場合しばしば主句が疑問形になり，反 問の意味を示すことである。

61. 晨莱不発迋, 唧罗米的运些稻草性?

62. 自己思想不革命化，念庶能領䓦好工 作呢?

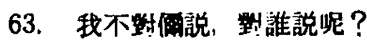

これらの例において，分句の间に条件関係が つくには、主句が反問になっていることがあ ずかってカがあると思われる。またこの例で はすべてそらであるが，従句が否定形で提起 されることである。否定形で提起された従句 はきわめて多いが，否定形で出されること自 身条件，譜歩を予測させるものをもつ。こと にこの例では後句がその上反問になるわけ で、連接関俰はきわ的てっきりでてくる。 その結果主語の存在ということで蒔接閣係を あいまいにする弱点は十分にカバーされてい 
るといえる。つまり主語がつくことは条件句 の従句に批いては莗接関保を不明確にするわ けで，従句のもつべ条件に反するか，その 不明確を補って十分なものが他にあるから， あえて主語をつけても問题にならないといら ことであろ5。.これに近い現象は主句が命令 句になる場合にも見られる。ただこれはそれ ほど明磪に指摘しらるむのではない。むしろ 問題となるのは次の上らな例である。

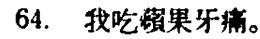

65. 僧那家信写起来没個完。

「わたしはリンコを食べると沾が痛くなる」 や「おまえの家へだす手紙仕まったく害きだ したらきりがない」の「我」や「吪那家信」 である。「我」は「吃蛏果」といら従句の述 部の行為主体であり，「俩那家信」は「写起 来」の主題である。いずれも従訽が主語をも っていると考えられる。しかしこれはこれら の句の自然な理解ではない上らである。つま りこれらの句に停頓を圈くとするなら，「吃 薜果」と「牙痛」の間よりも大きい停㛲が 「我」と「吃堵果」の间に置かれ5る。「写 起来」と「没個完」の间よりもさらに大きい

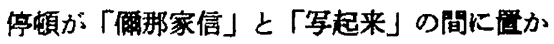
れらるのである。といらことは，これらの句 は「吃蹟果」や「写起来」といら従句か门我」 や「那家倞」といら主語をむっているのでは なく，「吃壦果牙痛」，「写起来没個完」と いった二命題表現がまずあり，それに主語が ついたと考えるべきである。ちょ5、ど「她肚 子大了」や「她脸杜了」と同種のなりたちを していると教えるべきだ思かれる。

つまり一般的にいって，策件中䁘步句には 主高门つかないのが普掘的である。つく場合 には相応の年件，理由を考えてよい（注13）。 主語といらべものをもたず，「要………, 得………」、「没有……没有……」, 「不 （就）……」よらな形が条件句など の常套的表現であることを考えれば，このこ とはかなり推察できることではないかと思 5 。

ただ韻歩句では梗端なもの，ありえないも
のをとりあげるならそれを主語として报らこ とができる性格があることは考えておかか性似

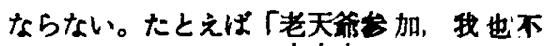
去」などである。

\section{(五)}

さきに，例 1 にあげた「有党支持，他排不住 网」について，四つの意味上の連姲の可能生 があるとのべた。しかし以上のよらに考えて くるとこれは垶りである。「有党」は明らか に「不確定表現」であるし、「何処に」とい 5，この句において教えられる「主語をむた ない」むしろ「党が支持している」といらこ との不確定表現として，このよらな句が成立 しているといえる。したがって当然これは 条件句か㜔步句（そのいずれであるかは願， 逆接にかかわるもので今は問わない）のいず れかに理解されるべきすのであって，因果句 や転折句にはとれないといわねばならない。 むし因果句や転折句であれば，少なくとも 「党支持我，他攔不住网」くらいにはならら と思われる。このよらな事情を無視して因果 や転折にとるのは俱りである。もっとも中国 語のよめる人はこのことを十分「カン」で心 得てはいるが。

そこで，最後に条件句中㜔歩句の一般的年 件といったものにふれてみたい。

「未然表現」，「不確定表現」，「主語を

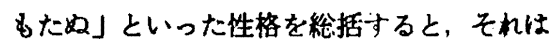
要するに「抽象レベルでの表現」であるとい える。といらことはまた，従句だけでは言い きりにならないで単句としての安定性を欠い た表現であるといらことでもある。主語がな いといらことは，単にそこで就ちいるとい らだけではなく，主語があることによって生 ずるであろらある主体の，乃至はある事実に ついての，生なしい具体的叙述，描写をして いないといらことである。たとえばさきにお げた例14において，「淩雲的姡子也有了工 作」はこれだけで単句として十分な資格をそ なえているわけでかなりいろんな文脈考 えてみても単独の表現として落ちつく。，しか 
し「度雲的嫂子也」を除き，「有了工作」と ナるなら、これはよ汪どその現われる場面を 限定しないことには単䖵の表現として用をな さない。一杸的叙述としては，まず「誰が」

「どらして」といった锳問なしには受けとめ られないのである。この句が安定して自らの 所を得るには「她毎月可以多給我十塊銭」を 後にとる必要がある。このことはこれらの従 句が、単句として不完全なものであるとい5 ことに他ならない。たとえシンタックスの上 では十分な単句と理解されるにしても，表現 としては，少なくともそれが成立するために きわめて特殊な文脈を前後に設定才る必要が あるとい5意味で，中国語の满足な単们の表 現とはとりがたいのである。「吃了飯」は言 いきりの形として文をなさないといわれる。

「吃了飯了」、「吃了三晼飯」の上5にい わかばならないとされる。このことは実は上 述のことと同し事実をいったるのである。

「吃了調」は grammatical を㹨義几解する なら，文法を無視した句とはいいがたい。し がし表現として，単独に言いきりで存在しな いといらことは，単句ではあるがなお十分な 叙述，描写を欠いているため成立しがたいと いらことである。十分な叙述，描写を欠くと はいろいろに解せるが、十分な限定語，状況 語をむた炑とであり、結果について言及し ないことであり，また未完結表現であるとい らことである。普過的事実か，事がらを抽象レ ヘハでのべるか，ある事実の存在不存在のみ を問題として言ら以外にありえないよらなる のとむいえる。いが英語における infinitive のよ5なものである。もっとも英語には 「John reads a book」は文法的ではあるが存 在しないといわれる。つまり「John reads books」とか 「John reads a book everyday」 のようになって現実に存在し：さきのような 表思は格言，一般的真理などとしてしか存在 しないといらのである。似たよらな現象であ るが、中国語ではこのよらなことがさらに多 くの所にあらわれるわけであって，このよう な表現を文法論の上で立てることは，有用な
ことであろらと思ら。

わたしはこのよらな表現を「素表現」と名 ふけておこらと思ら。いわ扔る「詞：辞」と いった分け方の「詞」とは多少意味がちが 5。必ずしも客体表現とい5ことではない。 また一時のヨーロッハのの中国学者、ザイデル などにおいていわれている動詞だけの問題と しての「アオリスト」(これはギリシャ語に 淤る無テンスについていったものである) でむない(泩14)。動詞の前後の成分をむ含め， 楼造として具体性を捁象した未完結表現で ある。このよらな表現は複句の従句のみなら す、他にもしばしば現われるものである。た とえば連動式の第一述部といわれるもの， 「武霞脱了性走進屋里去」の「脱了鞋」はこ の種のものといえよう。また把模文はこのよ らな表現と相容机ないものとして，その説明 に援用できそらである。さらに動詞文の embedding を考えるに当っては，このよう な考え方を一般的に利用できるのではなかる らかと考えるのである。

「他不好意思笑」は「かれは笑5にはぐあ いが悪かった」の意味で，「笑わなかった」 のである。しかし「他不好意思笑了」は「か れはぐあい悪そらに笑った」のである。この ちがいは「了」によるちがいと説明できる。 しかし別の見方をするなら「笑」と「笑了」 のちがいである。「笑」はいわば infinitive であり，素表現に近い。したがって主要述部 とはとられないわけであり，その結果として 「不好意思」が主要述部，「笑」は補語の上 らに理解される。しかしこれに反し，「笑 了」は具体的, 個別的主体について既成の事 物の敘述であり，その主体についての主要述 部ととられることになるのである。このこと はわたしののべる「素表現」といらことに直 接つながらないかむ知れないが，中国語に素 表現といら考えを導入する可能性を示唆する ものであり，そのよ5なものが中国語の根底 にあることを暗示するものといえとらであ る。（なお本稿は 42 年度文部省科学研究很に よる「中国語生成文法の研究」の一部をなす 
注 1 : 学校文典のたぐいにあげられている 得句はほとんど次のようなるのであ 万。

因為天策冷，所以河水結了冰。 如果再狫一会兒，水就開的。

しかしこれは砤句の見本にすぎない。 取実の故句にはこのよらな連接関係を

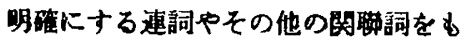
たないものがきわめて多い。したがっ てこのよらな見本だけの説明では数場 での用をなさない。これになんらかの 説明を与えてみよらといらのが本稿の 幽発点である。

注 2 ：「吾法和語法教学」（人民教育出版 社，1956）313頁。「漢語課本」第 5 用末見。

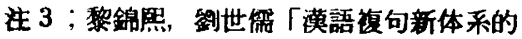

理諭」（中国語文 $1957 ， 8$ )

注 4 ：話しことばとしてこの句がでるなら イントネーション，ボーズなどによっ てその差が示されるであろら。ここで は畫かれたものとして报い，一応イン トネーションはさておく。

注 5 ：本稿にひく例文は次のものによる。 またこれらの例文に手を加えインフオ ーマントを経たものもある。

活剧「女店員」（老含，1959）

小説「欧陽海之歌」（金敬透，1966）

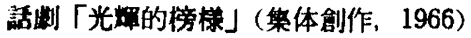

"「「紅岩」（李岩等編，1964）

" 「年青的一代」(陳枟等, 1963)

"「䣏收之后」(留澄，1963）

注 6 ：䦎野詞をどのよ5に考えるかは人に さってかなり立域の差がある。ぎわめ て広く考えれば「張三哭，本四笑」の 「張三」中「本四」「哭」と「笑」に あ関帏作用があるといらことにすらな
る。林裕文「编正復句」（上海教育出

版，1964）46面に詳しい。

注 7 :このよらな的係のたてかたは吕は湖 「語法学習」太太田展夫「中国語歴史文 法」などにみられる。

注 8 ：「明年我是学生」は事実として虯末 然であろらが，「我是学生」そのるの は米然表現ではない。つまり事実とし ての末然と末然表現とは区別されれば ならない。

注 9 ：「不是」になると末然になり5る。 「不」による否定のはたらきである 3。「不是耑的，誰能架那鹿大号?」 ただしこの埸合つねに後が疑問形をと る。このことは後にのべるとおりであ る。

注10：「既然」と同粎に已然を明確にする むのに「有了…」がある。「有了它，

俺就更不怕了」（それがあるからには ……) は既定の因果といえよう。

注11：関聯詞としての副詞のはたらきは壆 縮何において典型的である。漢語知碚 绕話「婜繀句」に詳しい。ただこれは 接繶関釈のみならず，他の表現価值に ともならすのが入ってくるため容易に 报えない面がある。

注12：前何にも後句にもかかる主語を，前 句の前に唇くか，後句の前に固くかに よって単句とするか度句とするか理解 がかわってくることに，現在の椱句の

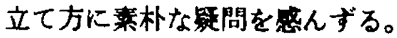
注13：もっとも「俩走了，我怎庭辦」のよ らな説明しがたいるのもある。たたこ れが中国人の心理のなかで、どの上5 に結びつく䙡句であるかは問題がある と思5。

注14: Sidel 「Chinesische Konversations Grammatik」175面。 